\title{
Regulating Sovereign Wealth Funds: When States Become Entrepreneurs
}

\author{
Gisela Mation*
}

\begin{abstract}
The rise of sovereign wealth funds and other forms of state-owned investments challenges the traditional role of the State and has generated unease at the global financial system. Are sovereign wealth funds motivated by purely commercial considerations? Could they be used to advance political interests? How should they be regulated? Most of the scholarship on the subject and the initiatives to regulate them advance the idea that the adequate behaviour for a state-owned fund is to act just as a private investor would. The 'privatisation' (understood as having the State behave like a private investor) of this type of investor is a way to deal with the practical consequences of their operation and also stabilise the standard theoretical conceptions on the market and the state. Although some 'privatisation' can be helpful, I propose to examine some of the consequences of looking at sovereign wealth funds solely through the lens of private law and private interest, in order to highlight possible pitfalls of this approach. In particular, suspicion about sovereign wealth funds has polarised the debate on their motivations: they are seen through a binary code of the good 'commerciallybased investment strategies' or the bad 'politically-driven' moves. This paper presents a more nuanced perspective on the non-commercially based considerations of sovereign wealth funds, in particular those considerations related to socio-economic development. Moreover, it advances the idea that the problem of governance of state-owned funds can be seen both from an external perspective-concerning the relation between the fund and the companies (or countries) receiving its resources-and from an internal perspective-concerning the relation between the fund and its constituents, such as the citizens of the investor state. While 'privatization' might provide good answers to deal with external governance, it is insufficient to tackle internal governance issues.
\end{abstract}

\section{Keywords}

Sovereign wealth funds; privatisation; private law; private interest; socio-economic development.

* $\quad$ LL.M. Harvard Law School, LL.M. University of São Paulo, LL.B. Fundação Getulio Vargas Law School. This article is a revised and summarised version of my Harvard Law School LL.M. thesis, developed under the supervision of Prof. Henier Kraakman. I am extremely grateful for Prof. Kraakman's excellent supervision. I would also like to thank the participants at the CJICL 5th Annual Conference on "Public and Private Power" and the CJICL editors for helpful comments. All errors are my own. 


\section{Introduction}

During the past decade, the total amount of investments made by states in the form of sovereign wealth funds (SWFs) has increased dramatically, both in number and size. The total amount of assets managed by SWFs amounted to USD 11.3 trillion in 2015 and is expected to reach 15.3 trillion by $2020 .{ }^{1}$ Additionally, over the past few years these funds have substantially changed their traditional investment policy of focusing on sovereign debt to include cross-border corporate transactions, seeking a diversified portfolio and higher returns. ${ }^{2}$ Their role as a source of capital in the aftermath of the 2008 financial crisis was critical, ${ }^{3}$ and at the time, 'the more common reaction to the expanded role of SWFs in the global financial system among the general public reflected a kind of collective unease. ${ }^{4}$

In many ways, the rise of SWFs has challenged the traditional role of the state and its relationship with the private sector. The privatisation of state-owned companies around the world, starting in the 1980s, was based on the argument that governments were not efficient managers and that state-owned business performed worse than those run by private actors. This privatisation movement might generate the impression that the state's participation in the economy, apart from its regulatory functions, was to be significantly reduced. The truth, however, is that while states have been selling their controlling interest in domestic companies, there has been a dramatic increase in their non-controlling equity stake in companies at home and especially abroad. $^{5}$

PWC, 'Sovereign Investors 2020' (2016) 7 <http://www.pwc.com/gx/en/sovereign-wealthinvestment-funds/publications/assets/sovereign-investors-2020.pdf $>$ accessed 22 November 2016.

2 Ronald Gilson and Curtis Milhaupt, 'Sovereign Wealth Funds and Corporate Governance: A Minimalist Response to the New Mercantilism' (2008) 60(5) Stan L Rev 1345, 1354.

3 For instance, after the beginning of the subprime mortgage crisis in 2007 until Jan 2008 alone, 'such funds have gambled almost $\$ 69$ billion on recapitalising the rich world's biggest investment banks': see 'Leaders: The Invasion of the Sovereign-Wealth Funds; Capital Markets' The Economist (London, 17 January 2008).

$4 \quad$ Kyle Hatton and Katharina Pistor, 'Maximizing Autonomy in the Shadow of Great Powers: The Political Economy of Sovereign Wealth Funds' (2011) 50 Colum J Transnatl L 1, 3.

5 See Bernardo Bortolotti, Veljko Fotak and William Megginson, 'The Rise of Sovereign Wealth Funds: Definition, Organization and Governance' in Stefano Caselli, Veronica Vecchi and Guido Corbetta (eds), Public Private Partnerships for Infrastructure and Business Development (Palgrave Macmillian 2015) 295: '[O]ver the 2001-2012 period governments acquired more assets through stock purchases (US\$1.52 trillion) than they sold through share issue privatizations and direct sales (US\$1.48 trillion)'. 
As investments by SWFs expand, many important questions arise: Are SWFs motivated by purely commercial considerations? Could they be used to advance political interests? How do they affect the relationship between 'home' countries (that own the funds) and 'host' or 'recipient' countries? Drawing the line between public and private power in SWFs' behaviour is at the heart of these questions, which become even more pressing with the increase and diversification of investments by SWFs.

In this context, a lot of debate has arisen on the issue of how such investments should be regulated, especially in the aftermath of the 2008 financial crisis. The general view was that SWFs should act as private investors would, and this is reflected in the main multilateral initiative to promote standards for the conduct of SWFs: the Santiago Principles. Created in 2008 by the International Working Group of Sovereign Wealth Funds, with the support of the International Monetary Fund, the Santiago Principles sought to 'demonstrate-to home and recipient countries, and the international financial markets - that the SWF arrangements are properly set up and investments are made on an economic and financial basis. ${ }^{6}$ Thus, one of the main objectives of SWFs, under the Santiago Principles, is to invest on the basis of economic and financial risk and return-related considerations."

In this article, I refer to these efforts to have SWFs' behaviour mimic that of a private investor as 'privatisation'. Thus, when used in quotation marks, I will not be referring to the ordinary meaning of the words privatisation or privatiseas they related to the transfer of a business, industry, or service from public to private ownership and control-but to initiatives, to have SWFs' behaviour match, as closely as possible, that of private investors. As is further explained below, the process of defining a regulatory framework or standards of behaviour for SWFs requires navigating the (sometimes artificial) separation between the realms of public and private powers, as well as theoretical conceptions of the market and the state. And while the 'privatisation' method can be helpful in designing rules to apply to this diverse array of entities classified as SWFs, I propose to examine three consequences of looking at SWFs solely through the lens of private law and private interest, in order to highlight possible pitfalls of this approach that seem to have been sometimes neglected in the policy debate. Practices: "Santiago Principles" (October 2008) $4<$ http://www.ifswf.org/sites/default/files/ santiagoprinciples_0_0.pdf $>$ accessed 22 November 2016. 
The first issue that arises from this current trend of privatisation is that, because of the fear about the motivations of state-owned funds, a 'presumption of bad intentions' might be created which would subject the funds to more scrutiny and limitations than private actors. This might hinder the general objective of making SWFs act as if they were private investors and might lead to market inefficiencies. Second, the suspicion directed at SWFs has created a false polarisation of their motivations: they are seen through a binary code of the good 'commercially-based investment strategies' or the bad 'politically-driven' moves. I wish to present a more nuanced perspective on the non-commercially based considerations of SWFs, in particular on those related to development.

Finally, the problem of governance of state-owned funds can be seen both from an external perspective-which concerns the relationship between the fund and the companies receiving its resources-and from an internal perspectiveconcerning the relationship between the fund and its constituents, such as the citizens of the investor state. 'Privatisation' might provide good answers to deal with external governance, but it is unclear how much it contributes to internal governance. In part, this seems to be due to the fact that the majority of proposals for the regulation of SWFs has been created and discussed in 'host' countries, and is thus based on the perspective and concerns of countries receiving capital. Thus, more research is required from the perspective of 'investor' states, which are more concerned with addressing issues of internal governance.

\section{Sovereign wealth funds: Problematic definitions}

When discussing the definition of SWFs, Stephen Grenville makes reference to a line by Humpty Dumpty in Lewis Carroll's Through the Looking Glass: A word means what you choose it to mean, neither more nor less.' This demonstrates that the term has been used to make reference to several types of institutions that tend to behave very differently. Some argue that the term SWFs 'began as an externally imposed category in search of a definition' and 'gained prominence in part because, as a group, they stand at the intersection of so many urgent governance concerns 
at once.9 The definition of SWFs is thus particularly fluid and contentious, and the developments in the institutions themselves seem to affect the definitions and categories used to describe them, as highlighted below.

Although no universal definition exists, ownership by the state seems to be the main common feature between the different classifications of state-owned funds. This is also a result of the diversity of entities and structures that could be considered state-owned funds: 'Sovereign investment vehicles embrace a large and protean class of organs, entities, and actions, whose principal point of commonality is the ownership, control, or management by a sovereign.. ${ }^{, 0}$ Apart from pointing out the ownership by the state as a feature of SWFs, many definitions also make reference to the specific functions of state-owned funds and distinguish these institutions from other pools of assets owned by the government, such as official reserves managed by a central bank for the purposes of liquidity.

Although the term 'Sovereign Wealth Funds' was coined only in 2005 by Andrew Rozanov, ${ }^{11}$ the use of funds by sovereign states to invest in the financial markets is not a new phenomenon. The first SWFs were created in the 1950s, by countries with significant reserves of natural resources, such as Kuwait (established in 1953) and Kiribati (established in 1956). These SWFs were created with the intention of protecting their economies from destabilisation of commodity prices and also as a means for preserving the benefits of non-renewable resources for future generations. ${ }^{12}$

SWFs have been established in a variety of forms, and since the 2000s, with the accumulation of foreign reserves that has happened in many of the emerging and the commodity exporting economies, the number of SWFs established by countries or even states (such as the Alaska Permanent Fund, in the US, and the Alberta Heritage Savings Trust Fund, Canada) grew significantly. ${ }^{13}$ It should be noted that some countries have established more than one SWF, usually

Anna Gelpern, 'Sovereignty, Accountability, and the Wealth Fund Governance Conundrum' (2010) 3 <http://ssrn.com/abstract=1639119> accessed 22 November 2016.

10 Larry Catá Backer, 'Sovereign Investing in Times of Crisis: Global Regulation of Sovereign Wealth Funds, State-owned Enterprises, and the Chinese Experience' (2010) 19 Transnatl L \& Contemp Problems 3, 59.

11 The creation of the term is attributed by several authors to Andrew Rozanov, in an article written in 2005. See Andrew Rozanov, 'Who Holds the Wealth of the Nations?' (2005) 15 Cent Banking J 52, 52-53.

12 Grenville (n 8) 18.

13 See, eg, 'Sovereign Wealth Fund Rankings' Sovereign Wealth Fund Institute <http://www. swfinstitute.org/sovereign-wealth-fund-rankings/> accessed 16 January 2017. 
with different investment strategies, as is the case in the United Arab Emirates, ${ }^{14}$ Singapore $^{15}$ and Venezuela. ${ }^{16}$

The important features of the historical development of SWFs encompass not only their significant growth in size and volume, but also a change in their investment strategies. Traditionally, foreign reserves would be invested in government bonds and treasury bills from developed economies. As a way to maximise return on their foreign reserves, states started to deviate from this traditional investment strategy focused on sovereign debt and began to invest in a 'much broader array of assets, including stocks, bonds, fixed assets, commodities, derivatives, and alternative investments, such as real estate and hedge funds. ${ }^{, 17}$ Investments by SWFs are now much more profiled and risky.

Moving beyond ownership by the state as a baseline for defining SWFs, it should be noted that, as Gilson and Milhaupt explain, SWFs are just one among the diverse types of vehicles of state investment. These vehicles include central banks on one end of the spectrum and state-owned enterprises on the other. ${ }^{18}$ Thus, the numerous definitions and classifications that have been proposed can include or exclude different types of vehicles of state investment. Besides ownership by the state, some definitions establish specific functions for SWFs, or even classify them in terms of the source of their funds or even by region.

The functions attributed to SWFs are very diverse, and the following list, from Kozack et al, seems to encompass most of the different objectives and functions referred to by the literature on SWFs:

(i) insulating the budget and economy from excess volatility in revenues; (ii) helping monetary authorities sterilize unwanted liquidity; (iii) building up savings for future generations; (iv) accumulating funds to meet future public pension obligations;

Abu Dhabi Investment Authority and Corporation, Mubadala Development Company and Istithmar. files/20090115_RL34336_a7ea655551d2435a8e05992d4ac1b1367b3e3635.pdf> accessed 22 November 2016; Gilson and Milhaupt (n 2) 1347-48. 
(v) increasing the return on reserves; and/or (vi) promoting economic and social development. $^{19}$

The great diversity of the institutions that could be put under the term 'sovereign wealth fund' is of particular relevance for regulatory policies. Regulatory measures that are fit to deal with problems of one type of SWFs might be unsuited to regulate others. ${ }^{20}$ Thus, some of the challenges when discussing regulation of SWFs lie in designing regulations and definitions that are adequate to deal with their diversity of forms and functions.

\section{Clash of ideas: Concepts on the role of the state in the market economy}

SWFs have raised a great deal of concern about both their theoretical implications and their practical consequences, both of which will guide the policy debate. From a theoretical standpoint, SWFs could be understood as challenging the traditional concepts of the market economy and affect the 'proper' workings of capitalism that could impose barriers to SWFs. Such restrictions will, in most cases, inhibit the free flow of trade and capital, and this is what could be considered 'anti-capitalist'. Thus, one of the main challenges that regulators face when designing and discussing policies to regulate SWFs is the balance between addressing the different types of concerns that these funds raise and adopting measures that are in one way or another protectionist and contradict the idea of an open market.

Over the 20th century, a lot of effort has been devoted to debating and defining the role of the state in a capitalist economy. As state-owned funds are one of the instruments for state intervention in the economy, the debate on SWFs is embedded in this general discussion. Part of the fuss about the rise of SWFs is due to the fact that, to certain authors and government officials, their mere existence can be interpreted as putting into question some of the 'most basic assumptions about the structure and functioning of our economies and the international financial 
system. ${ }^{21}$ With new forms of government intervention, the 'conventional premise of political and economic organization (...) that state actors regulate markets in which non-state actors participate-is now challenged by the activities of states that participate in markets and non-state actors that seek to regulate. ${ }^{, 2}$

Gilson and Milhaupt argue that the controversy surrounding state-owned funds is one of the results of the interaction between two different conceptions of the role of the state in a capitalist economy: 'state capitalism' and 'market capitalism. State capitalism is often identified with the approach that some emerging economies have taken in the role of government for economic development. ${ }^{24}$ Others define state capitalism more generally as 'a system in which the state dominates markets, primarily for political gain' and argue that every country 'features both direct government involvement in regulating the economic activity and some market exchange that exists beyond the state's reach. ${ }^{25}$

This general debate on the role of the state in the market economy and on different types of capitalism is easily translated into SWFs. As Christopher Cox, former Chairman of the US Securities and Exchange Commission stated:

These differences in the way we see the role of government-in America's case, as neutral arbiter and enforcer of the rules of the market, and in many other countries, as both player and referee-can have significant implications for the workings of the free market itself. ${ }^{26}$

One of the novelties that SWFs bring to the debate on the role of the state is that the state regulating the financial sector and the state acting as a private player in the market are usually not the same state. As explained above, the discussions of the role of the state usually assume a single state, and not the interaction between different sovereign states. This has implications, not only for the theories of state

Sovereign Wealth Fund Acquisitions and Other Foreign Government Investments in the United States: Assessing the Economic and National Security Implications: Hearing Before the Senate Committee on Banking, Housing and Urban Affairs, 110th Congress (2007) (testimony of Edwin M Truman, Senior Fellow, Peterson Institute for International Economics) cited by Gilson and Milhaupt (n 2) 1347.

Backer, 'Sovereign Investing in Times of Crisis' (n 10) 16.

Gilson and Milhaupt (n 2) 1346.

ibid.

Ian Bremmer, The End of The Free Market: Who Wins the War Between States and Corporations (Penguin 2010) 43.

Christopher Cox, 'The Rise of Sovereign Business' (5 December 2007) <http://www.sec.gov/ news/speech/2007/spch120507cc.htm> accessed 22 November 2016. 
intervention in the economy, but also for international relations and world politics. Other authors argue that SWFs seem not only to challenge the traditional ideas of the role of government in the economy, but also to blur the distinctions between public and private in a new fashion, arising from the 'usurpation of private power by foreign public actors that reach across borders. ${ }^{27}$

Knowing whether SWFs are a challenge to the neoliberal paradigm of intervention of the state in the government or whether they are actually the ultimate realisation of neoliberalism, since even the states would be operating as private players, is critical to the debate on their regulation. If SWFs are understood to be like private actors in the market, the regulatory approach could be giving states the same treatment as private entities. If SWFs are understood as extensions of state national power, the solution for regulating these institutions might have to be political. ${ }^{28}$ In this sense, the theoretical framework that informs the debate on SWFs borrows from the discussions of private agents maximising their interests to the detriment of the company in which their investment is made. As discussed in Part IV below, fiduciary duties that operate under corporate law are one way of preventing this type of behaviour.

Even those who contend that the idea of the state acting as a private investor in the market departs from the neoliberal paradigm of state intervention seem to recognise that, on the other hand, restricting foreign state investment would be a type of protectionism, which in turn, would not be aligned with neoliberal policies. This poses a dilemma for regulatory policies in financial markets, and requires regulatory agencies to find a fine balance between what could be seen as protectionism and allowing for a (foreign) state to be a significant player in the market. This balance is rendered even more difficult to achieve in a time of crisis, as any policy restricting investment by foreign state-owned funds would outflow capital in a time when its scarcity is yet another problem that regulators have to deal with. As Rose puts it, '[w]hile equity investments by SWFs raise serious political and economic concerns, the converse problem of no investment from these very wealthy funds may also pose serious long-term threats to sustained economic prosperity. ${ }^{29}$

In this theoretical framework about the workings of the market, the debate on regulating SWFs is very frequently informed by the binary code of SWFs

28 ibid 5.

29 Paul Rose, 'Sovereigns as Shareholders' (2008) 87 North Carol LR 83, 90-91. 
behaving either as: (i) rational wealth-maximising agents (and thus being good for the market); or (ii) states advancing their political goals (which, as explained above, would be considered particularly threatening to some). Among the few who present an alternative view, Hatton and Pistor state that SWFs are 'autonomymaximizing institutions, ${ }^{30}$ and are used by ruling elites 'to secure their domestic political dominance against both internal and external threats. ${ }^{31}$ This means that SWFs are not rational wealth-maximising agents, but they are also not advancing their home countries' geopolitical agenda. While some other explanations of the motivation of SWFs beyond the binary code of wealth-maximising and geopolitical agendas are presented, I contend that more focus is needed on non-commercial purposes of SWFs which are unrelated to these so-called geopolitical goals.

\section{Regulatory framework on state-owned funds}

In most recipient countries, a diverse array of domestic rules affect the operations of SWFs in their territories. In a broader sense, these funds are obviously subject to all rules of regulation of financial markets and corporate law that would apply to any investor in a company incorporated or listed in that country. Moreover, some countries, such as the US, have established a specific regime governing foreign investment (made by a private party or by a foreign government), with particular concerns for national security. ${ }^{32}$ For the purpose of this article, however, I will focus on what is considered to be the most relevant regulatory framework that applies specifically to SWFs, which has been created at a transnational level.

The most prominent initiatives to promote regulation of SWFs have taken place on the multilateral fora of the International Monetary Fund (IMF) and the Organization for Economic Cooperation and Development (OECD). In both cases, the institutions have attempted to influence the regulatory landscape by soft law, producing guidelines or reports on best practices for voluntary compliance. In

31 ibid.

32 Section 721 Defense Production Act of 1950, as amended by the Foreign Investment and National Security Act of 2007, establishes the authority to review mergers, acquisitions, and takeovers that could result in foreign control or control by foreign governments, in regard to its effect to the national security of the US. This review is performed by the Committee on Foreign Investment in the United States ('CFIUS'), created in 1975 by the Executive Order 11858 with the mandate to carry out Section 721. 
terms of their direct audience, they are each at one end of the regulatory spectrum: the IMF is focused on best practices for SWFs themselves, whereas the guidelines of the OECD report are meant for capital-receiving countries. Even before these institutions addressed the specific issue of SWFs, they already had more general guidelines with principles that could be applied to SWFs or inspire their specific regulation-the IMF established the 2001 Guidelines for Foreign Exchange Reserve Management, ${ }^{33}$ and the OECD created the 2005 Guidelines on Corporate Governance of State-Owned Enterprises. ${ }^{34}$ It should be noted that, before the guidelines and best practices established by the IMF and the OECD, the European Commission had already published a report on SWFs, which contains some of the main principles of the subsequent initiatives.

It is suggested that the US Treasury had an important influence over the international initiatives of regulating SWFs. In June 2007, US Under Secretary for International Affairs, Clay Lowery, claimed that the issue should be discussed in multilateral fora, and that 'the IMF and World Bank could take a very constructive step through the drafting of best practices for Sovereign Wealth Funds. ${ }^{35}$ After that, Secretary of the Treasury, Henry Paulson, is said to have included the topic in the agenda of the G7 by 2007 and 'nudged' the IMF, OECD and the World Bank to 'take on the task of overseeing the development of the SWFs' "best practices" project."

It should be noted that, at the same time as the US sought to develop a set of best practices within international organisations, it also tried to establish agreements directly with SWFs. It secured an agreement with the SWFs of Abu Dhabi and Singapore, issued on March 2008 and based on their 'common interest in an open and stable international financial system. ${ }^{37}$ This agreement seems to

33 International Monetary Fund, 'Guidelines for Foreign Exchange Reserve Management' (2001) <http://www.imf.org/external/np/mae/ferm/eng/index.htm> accessed 22 November 2016.

34 Organization for Economic Cooperation and Development, 'OECD Guidelines on Corporate Governance of State-Owned Enterprises' (2005) <http://www.oecd.org/daf/ca/oecdguidelines-corporate-governance-soes-2005.htm> accessed 22 November 2016.

35 US Department of the Treasury, 'Remarks by Acting Under Secretary for International Affairs Clay Lowery on Sovereign Wealth Funds and the International Financial System' (21 June 2007) <http://www.treasury.gov/press-center/press-releases/Pages/hp471.aspx> accessed 18 September 2016.

36 Joseph Norton, "The "Santiago Principles" for Sovereign Wealth Funds: A Case Study on International Financial Standard-Setting Processes' (2010) 13 J Intl Econ L 645, 651.

37 US Department of the Treasury, 'Treasury Reaches Agreement on Principles for Sovereign Wealth Fund Investment with Singapore and Abu Dhabi' (20 March 2008) <http://www. treasury.gov/press-center/press-releases/Pages/hp881.aspx > accessed 22 November 2016. 
enunciate the main principles that were later developed in the international fora. With regard to SWFs, it states that investment decisions should be based solely on commercial grounds'; 'SWFs should have in place strong governance structures, internal controls, and operational and risk management systems'; 'SWFs and the private sector should compete fairly'; and 'SWFs should respect host-country rules by complying with all applicable regulatory and disclosure requirements. ${ }^{38}$ The part of the agreement that concerns disclosure is much less specific, simply stating that:

Greater information disclosure by SWFs, in areas such as purpose, investment objectives, institutional arrangements, and financial information-particularly asset allocation, benchmarks, and rates of return over appropriate historical periods-can help reduce uncertainty in financial markets and build trust in recipient countries. ${ }^{39}$

With regard to receiving countries, the agreement says that they 'should not erect protectionist barriers to portfolio or foreign direct investment'; should 'ensure predictable investment frameworks'; should 'respect investor decisions by being as unintrusive as possible, rather than seeking to direct SWF investment'; and 'should not discriminate among investors. ${ }^{40}$ Moreover, it discusses the issue of national security, saying that '[a]ny restrictions imposed on investments for national security reasons should be proportional to genuine national security risks raised by the transaction. ${ }^{41}$ As shown below, these principles sum up the main elements established by the IMF and the OECD when providing guidelines and best practices for regulating SWFs.

By the end of 2007, the IMF organised a roundtable with sovereign asset and reserve managers and started a comprehensive study on the practices and organisation of the existing SWFs. On February 2008, it established a 'Work Agenda' for SWFs that would guide the creation of best practices. In this framework, the International Working Group of Sovereign Wealth Funds (IWG) was created in May 2008 at a meeting of countries with SWFs, in addition to countries and international organisations who participate in the capacity of observers. The goals of the IWG are: (i) 'to help maintain a stable global financial system and free flow of capital and investment'; (ii) 'to comply with all applicable regulatory and disclosure requirements in the countries in which they invest'; (iii) 'to invest on the basis of 
economic and financial risk and return-related considerations'; and (iv) 'to have in place a transparent and sound governance structure that provides for adequate operational controls, risk management, and accountability. ${ }^{42}$

The IWG started discussions on the creation of best practices for SWFs and met three times - in Washington, Singapore, and Santiago (Chile)—for this purpose. The Generally Accepted Principles and Practices, also known as 'Santiago Principles' or 'GAPP' were published in October 2008 by the IWG. It is an instrument of soft law, as it is 'a voluntary set of principles and practices that the members of the IWG support and either have implemented or aspire to implement, ${ }^{43}$ and each of the principles is accompanied by an explanation and commentary.

The Santiago Principles are divided into three sections: Principles 1 to 5 deal with the legal framework, objectives and coordination with macroeconomic policies; Principles 6 to 17 refer to the institutional framework and governance of SWFs; and finally, Principles 18 to 24 deal with the investment policy and risk management framework. They require determination and disclosure of the fund's legal structure; ${ }^{44}$ policy purposes; ${ }^{45}$ procedures and rules for funding, withdrawal, and spending operations; ${ }^{46}$ source of funding; ${ }^{47}$ procedure for appointing governing authorities; ${ }^{48}$ and accountability framework. ${ }^{49}$ The guidelines also broadly concern governance:

The governance framework for the SWF should be sound and establish a clear and effective division of roles and responsibilities in order to facilitate accountability and operational independence in the management of the SWF to pursue its objectives. ${ }^{50}$

The principles establish a set of reporting requirements, such as an annual report and accompanying financial statements, as well as an annual audit.

On July 2011, almost three years after the publication of the Santiago Principles, the International Forum of SWFs (IFSWF), a global network that succeeded the IWG, published a report on the 'IFSWF Members' Experiences in the Application of

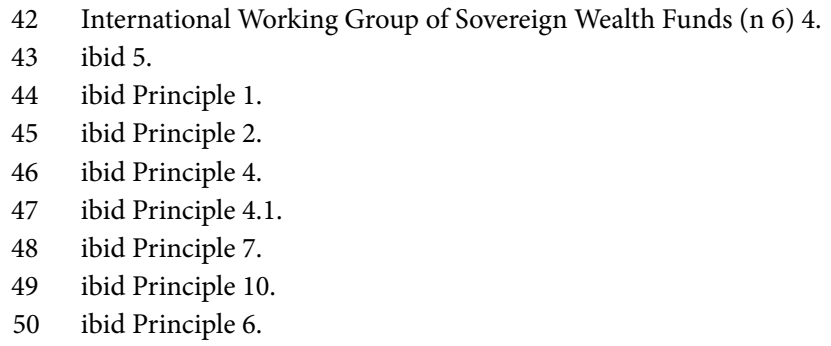


the Santiago Principles', analysing results self-reported by its members. The report is, overall, positive, in the sense that it conveys that a strong level of compliance with the Santiago Principles exists. With regard to transparency, the report finds that 'most Members disclose their legal basis and structure to the public' as well as their policy objectives. More than half of the funds do not have a procedure for coordinating their policies with those of monetary and fiscal authorities, 'mainly because they are not directly involved in or do not affect macroeconomic policies.

Interestingly, most members report that they were already in compliance with the Santiago Principles before they were created. ${ }^{52}$ Members of the International Forum of Sovereign Wealth Funds have reported that disclosure of their legal basis and structure to the public 'facilitates public understanding and trust of management, and therefore it has a positive impact on domestic legitimacy. ${ }^{53}$

At the request of G7 Finance Ministers and as part of an ongoing project on 'Freedom of Investment and National Security and Strategic Industries', the OECD prepared its report on 'Sovereign Wealth Funds and Recipient Countries, published in October 2008. It should be noted that the report is relatively general, and is not on the same level of specificity as the rules of the Santiago Principles. The report advocates for policies of fair treatment of investment and principles of 'non-discrimination, transparency [regarding the information on restrictions on foreign investment] and liberalisation ${ }^{55}$ as well as a standstill commitment not to introduce new restrictions, ${ }^{56}$ which already existed in previous OECD investment instruments in a more general fashion. It recognises the members' right to take actions necessary to protect national security, expressed in Article 3 of the OECD Codes of Liberalisation of Capital Movements and Current Invisible Transactions, but it has been stressed that its members 'have agreed that [it] should be applied

International Forum of Sovereign Wealth Funds, 'IFSWF Members' Experience in the Application of the Santiago Principles' (2011) $14<$ http://www.ifswf.org/sites/default/files/ Publications/stp070711_0.pdf > accessed 22 November 2016. ibid 17.

53 ibid 13.

54 Organization for Economic Cooperation and Development, 'Sovereign Wealth Funds and Recipient Countries - Working Together to Maintain and Expand Freedom of Investment' (11 October 2008) <http://www.oecd.org/investment/investment-policy/41456730.pdf> accessed 22 November 2016. ibid 1.

56 ibid 3. 
with restraint and should not be a general escape clause from their commitments to open investment policies. ${ }^{57}$

The report provides specific guidance for: investment policy measures designed to safeguard national security in the areas of (i) non-discrimination; (ii) transparency/predictability, which includes the codification and publication of rules, giving prior notice of a country's intention to change investment regulation policies and allowing for consultations; (iii) regulatory proportionality. It is for each country to decide on what the measures necessary to protect national security are.

While both the Santiago Principles and the OECD recommendations in its 'Sovereign Wealth Funds and Recipient Countries' report advance transparency and accountability within SWFs, this is generally done through the perspective of governance and accountability between funds and their invested companies or the home states in which such assets are located. As will be highlighted below, the increasing use of SWFs for goals other than wealth maximisation puts the comprehensiveness and relevance of this regulatory framework into question.

\section{5 'Privatising' the state}

As explained above, the debate on the regulation of SWFs has been dominated by a general assumption that they need to become as close to non-state investors as possible, as if they were 'sovereigns pretending to be non-sovereigns in their participation in global private economic markets. ${ }^{58}$ Despite the diversity of the debate regarding the regulation of investments by the state, there seems to be a consensus that SWFs should be acting like rational financial profit-maximising agents in order to engage with the capitalist economy because:

effectively, if a sovereign wealth fund acts like a private investor, if it ceases to exercise its authority as a regulator rather than a participant, then it ought to be

57 Organization for Economic Cooperation and Development, 'Sovereign Wealth Funds and Recipient Countries - Working Together to Maintain and Expand Freedom of Investment' (11 October 2008) <http://www.oecd.org/investment/investment-policy/41456730.pdf> accessed 22 November 2016; Carolyn Ervin, 'Sovereign Wealth Funds - Should sovereign wealth funds be treated differently than other investors? An OECD project has set out to answer this question' (2008) OECD Observer No 267 <http://oecdobserver.org/news/archivestory.php/ aid/2610/Sovereign_wealth_funds.html> accessed 16 January 2017.

Backer, 'Sovereign Investing in Times of Crisis' (n 10) 20. 
viewed as a benign instrument useful to the development of global financial markets, and regulated as such. ${ }^{59}$

This attempt to 'privatise' SWFs poses significant challenges. First, there is the question of whether SWFs can really be 'privatised'; in other words, can SWFs truly conduct themselves as private investors would (A). Second, there is the issue of dealing with non-commercial goals of SWFs-which are, as stated above, not necessarily advancing a geopolitical agenda (B). Third, we must examine whether the governance of SWFs can be dealt with satisfactorily through the lens of private power (C).

\subsection{Not so 'private': Challenges of the 'fiduciary state'}

The first challenge to the 'privatisation' of SWFs has both theoretical grounds and practical considerations. Can SWFs really act as private investors? In answering the theoretical question, many scholars and commentators seem to have adopted a realist approach, in the sense that states are viewed as always maximising their own national political interests, and incapable of acting simply to maximise financial gains. The debate in the US Congress summarises the general idea: 'By definition, these funds are extensions of the state, and should always be viewed as maximizing their nation's strategic interests, in addition to maximizing profits. ${ }^{60}$ This would, in turn, put in to question the very logic of this regulatory attempt to 'privatise' these investment vehicles:

The current SWF form seems to be the source of looming institutional contradictions. On the face of it, these funds swear off national, or strategic investment strategies in deference to Western sensibilities. Nevertheless, they ultimately exist to serve the sovereign sponsor. Gelpern (2010) articulates this dilemma in the following way: 'Reading between the lines of SWF definition and commentary reveals a jumble of contradictions: public money that pledges to act private, vast pools of capital that

59 Larry Catá Backer, 'Sovereign Wealth as Regulatory Chameleons: The Norwegian Sovereign Wealth Funds and Public Global Governance Through Private Global Investment' (2010) 41 Geo J Intl L 425, 430.

60 Chairman Gutierrez, 'Sovereign Wealth Funds: New Challenges from a Changing Landscape: Hearing before the Subcommittee on Domestic and International Monetary Policy' (10 September 2008) Trade and Technology of the Committee on Financial Services, US House of Representatives, 110th Congress, Serial No 110-37 <http://www.gpo.gov/fdsys/pkg/CHRG110hhrg45621/pdf/CHRG-110hhrg45621.pdf> accessed 22 November 2016. 
promise not to move markets, non-controlling investors that manage centrally controlled economies, and public fiduciaries that balk at corporate governance of their investment targets.' While SWFs claim to pursue financial profit alone, there nonetheless remains the long-term interest of the nation-state in using its sovereign wealth to advance status and fortunes of the sponsoring nation as a whole. ${ }^{61}$

Despite this view that SWFs would always maximise the interest of their nationstates and as much as they are feared, it is hard to find examples of misconduct in their investment strategies. Moreover, they are often considered to be relatively conservative investors, focused on the long-term and with 'buy and hold' investment strategies. ${ }^{62}$ After the financial crisis, it has been suggested that this has partially changed, with certain funds taking on more aggressive strategies and investing in private equity and hedge funds, 'indirectly financing highly leveraged strategies. ${ }^{63}$ However, no hard evidence of misuse of SWFs has been presented. Not only have SWFs not 'misbehaved', but an argument could be made that they could not do so even if they wanted to: in general, SWFs have been investing in minority stakes, which would give them limited ability to influence management.

First, there is the theoretical challenge of knowing whether SWFs would be capable of acting as private investors (or whether they would always actively use their investments as means of exercising their political power). Second, many have questioned whether, at the other end of the spectrum, they would be subject to such strict scrutiny that they would become more passive than private investors. In that sense, this shift from the state as an owner of companies to the state as an investor has given rise to the 'fiduciary state. ${ }^{64}$ But will the state exercise its fiduciary duties to the companies in which it invests in the same way that private investors would?

Bernstein et al have conducted detailed research on the strategies of SWFs between 1984 and 2007, analysing 2,662 investments and examining 'the propensity of the funds to invest domestically, the equity price levels at the time of their investment, the changes in equity prices after their investment, and the size of

61 Gordon L Clark, Adam D Dixon and Ashby HB Monk, Sovereign Wealth Funds: Legitimacy, Governance and Global Power (Princeton UP 2013) 8.

62 Kozack, Laxton and Srinivasan (n 19) 31.

63 ibid.

64 Bernardo Bortolotti, Veljko Fotak and William Megginson, 'The Rise of Sovereign Wealth Funds: Definition, Organization and Governance' in Stefano Caselli, Veronica Vecchi and Guido Corbetta (eds), Public Private Partnerships for Infrastructure and Business Development (Palgrave Macmillian 2015) 296. 
the acquired stakes. ${ }^{65}$ According to the study, SWFs from Asia and the Middle East tend to acquire bigger stakes in the capital-receiving companies than their Western counterparts. ${ }^{66}$ Moreover, the study finds that funds operated by external managers have a slight tendency to invest in smaller stakes. ${ }^{67}$

It is clear that, even in the cases in which SWFs hold a greater stake, they are under strict political scrutiny, and the consequences of participating in transactions that could potentially be seen as politically motivated go beyond the specific operation at hand, as it could be taken into account by the CFIUS when analysing other future deals. Thus, 'SWFs should rationally seek to avoid uncertainty and potentially heavy regulatory burdens that would result from a deviation from a default investment posture. ${ }^{68}$

The debate on the rise of SWFs has put them in the spotlight in the exercise of their activities. The level of disclosure that is expected of SWFs (by domestic regulation, by international instruments of soft law, like the Santiago Principles, and by the media) is considerably higher than that applicable to private investors. SWFs are encouraged not to behave as active investors, and their transactions are subject to much higher scrutiny.

One of the possible effects of this process is that SWFs will be less willing to engage in corporate governance than a private investor would, making management in the recipient company more powerful and less accountable. An example of this phenomenon could be observed in the purchase of Citibank stocks by the Abu Dhabi Investment Authority. As a condition to the transaction, the fund agreed 'not to own more than a $4.9 \%$ state in Citi, and will have no special rights of Wealth Funds' (2009) 3 <http://www.hbs.edu/research/pdf/09-112.pdf > accessed 22 November 2016.

66 ibid 24

67 ibid 27. It should be noted that a few exceptions to this general rule of minority participation exist. In 2006, for instance, Tamasek Holdings (owned by the Government of Singapore) and a group of Thai investors purchase a $49.6 \%$ stake in Shin Corp (Thailand's largest telecommunications company and at the time seventh largest listed company) from Thailand's Prime Minister Thaksin and his family, which triggered a mandatory offer for the remaining stocks. This resulted in Temasek and its partners having a 96\% stake in Shin Corp; See 'Temasek Sells Down Thai Telecom Asset At Loss' Forbes (19 August 2011) <http://www.forbes.com/sites/ simonmontlake/2011/08/19/temasek-sells-down-thai-telecom-asset-at-loss/\#5e3ecac54d03> accessed 16 January 2017; 'Corporate Structure of Shin Corporation Public Company Limited' Siam Premier (Bangkok, 7 January 2007) <http://siampremier.com/corporate-structure-ofshin-corporation-public-company-limited/> accessed 16 January 2017. Rose (n 29) 101. 
ownership or control and no role in management or governance of Citi, including no right to designate a member of the Citi Board of Directors. ${ }^{69}$

In the same vein, in trying to solve the problem of the potential conflict of interest of SWFs when exercising their ability to influence management, Gilson and Milhaupt have proposed that voting rights be suspended while the respective stocks are owned by a foreign state. According to the authors:

The result is to separate control from investment value, the expected returns to a foreign-sovereign equity investor remain identical to those of other shareholders, yet the foreign government entities lose direct influence over management through voting. ${ }^{70}$

Supposedly, state-owned funds motivated solely by financial returns would still invest, and those interested in pursuing political goals would not.

Although this proposal and the limitation on the Abu Dhabi Investment Authority's influence on Citibank's management could possibly prevent a SWF from unduly interfering with the company's business, it also imposes a passive investment behaviour that has been so criticised in the American reality of disperse share ownership. Moreover, SWFs might refrain from taking actions that maximise the company's profit simply because they might potentially look suspicious in the public eye. As Rose explains, '[t]he suspicion surrounding SWFs will likely cause SWFs to act hypercautiously. ${ }^{71}$ As an example, he refers to the situation in which:

[U]nlike other investors not operating under political suspicion, SWFs may fear that suggesting cost-cutting measures could be viewed as a politically motivated effort to encourage outsourcing (perhaps to the SWF's home country). Because of fears that the SWF will be used as a political tool of the state, the SWF must consider the potential political effect of any action or statement it or the sovereign makes regarding its investment. ${ }^{72}$

In other words, the general discomfort with SWFs that apparently motivates the attempt to 'privatise' these institutions and their behaviour could backfire; all the (26 November 2007) <http://www.citigroup.com/citi/news/2007/071126j.htm> accessed 22 November 2016.

$70 \quad$ Gilson and Milhaupt (n 2) 1352.

71 Rose (n 29) 102.

72 ibid. 
suspicion against government investment vehicles could lead them to behave inefficiently.

\subsection{Different types of non-commercial motivations of SWFs}

As explained in Part IV above, a lot of the discussion on the regulation of SWF has been driven by the idea that these investment vehicles would be used for 'political' motivations. The idea of 'political' interests in this case is very negatively charged, and is associated with the misuse of the stake in a foreign country for measures of foreign policy and to advance geopolitical causes that concern national security. A dichotomy is established between purely financial considerations and political interests, as if these were the only two options of behaviour of a SWF. This paper wishes to propose a more nuanced look at the considerations that a SWF could take into account in the elaboration of its investment strategy. Apart from saying that there is more than the binary code of SWFs being driven by maximising the return on investment they receive by dividends or increase in share value versus geopolitical objectives, it wishes to show that certain types of non-commercial objectives by SWFs are not to be feared. In this sense, if we accept that SWFs might take on purposes that are not limited to those 'commercially motivated', their form and regulation can change dramatically. As Clark and Monk put it:

The form of SWFs may not be stable over the long-term; the challenge facing SWFs is, in part, about transcending traditional forms of investment management in favour of a genuine commitment to long-term investment in the interest of both the SWF and the sovereign. ${ }^{73}$

SWFs can receive benefits from their investment by a variety of means. Dividends and an increase in share values are not the only types of return a SWF could expect from an investment. For instance, a state-owned fund could choose to invest in a company producing technology that is needed in the home country, or to allocate capital to firms willing to open branches in its country and develop the local economy. As shown below, this is very different from a fund using its investment abroad to illegally gain knowledge about technology or to exercise influence over the capital receiving country. Rose discusses this argument by elaborating on the 
possibility that a fund would encourage a company to build a factory in a country in order to 'provide jobs, diversify the economy, and strengthen the country's tax base', without it representing a breach of fiduciary duties. ${ }^{74}$ It should be noted that, among the non-profit maximisation goals that a SWF could choose to pursue, is the inclusion of social responsibility requirements in its investments. In fact, this type of non-commercial objective of a SWF not only already exists in practice, but no concerns seem to be raised about the fact that the logic behind the fund's behaviour is not exclusively wealth-maximisation.

The Norwegian Government Pension Fund, often cited as the role model for sovereign funds' accountability and transparency, is one of the most prominent examples of SWF with social and environmental requirements imposed on capital-receiving companies. ${ }^{75}$ Companies in which the Norwegian Government Pension Fund holds stakes may be excluded or put under observation if there is an unacceptable risk that the company contributes to or is responsible for a wide array of wrongful conducts, including human rights violations, environmental damage, unacceptable greenhouse gas emissions, corruption and 'other particularly serious violations of fundamental ethical norms. ${ }^{76}$

Moreover, the Norwegian fund is not allowed to invest in companies that produce tobacco or weapons, or mining or power companies deriving $30 \%$ or more of their income from thermal coal or basing $30 \%$ or more of their operations on thermal coal. ${ }^{77}$ Currently, this SWF owns more than $2 \%$ of all listed shares in Europe and over $1 \%$ of listed shares globally. ${ }^{78}$ In addition to rules on acceptable conduct, the Norwegian fund has focused a significant part of its investments in companies contributing to three areas of sustainability: children's rights, climate change and water management.

Apart from promoting social responsibility, another benign non-commercial objective to be pursued by SWFs-which has been gradually recognised by

75 See Simon Chesterman, 'The Turn to Ethics: Divestment from Multinational Corporations for Human Rights Violations - The Case of Norway's Sovereign Wealth Fund' (2008) 23 Am U Intl LR 577.

76 Norges Bank Investment Management, Guidelines for the Observation and Exclusion from the Fund (9 February 2016) Section 3 <http://www.nbim.no/en/the-fund/governance-model/ guidelines-for-observation-and-exclusion-from-the-fund> accessed 21 September 2016.

77 ibid Section 2.

78 'Norway's Global Fund - How Not to Spend It' The Economist (London, 24 September 2016) $<$ http://www.economist.com/news/business-and-finance/21707435-norways-global-fund-itstough-small-democracy-run-worlds-biggest> accessed 27 November 2016. 
scholarship and international organisations-could be development. In 2009, the IMF released a working paper on the practical issues involved when establishing a SWF, and, while classifying the funds in accordance with their objectives, acknowledged explicitly 'development funds that use their returns to invest for development purposes. ${ }^{\text {,7 }}$

In practice, however, SWFs have increasingly invested in infrastructure ${ }^{80}$ and made their investment decisions based on development goals. More recent studies on the practice and organisation of SWFs used a taxonomy that encompasses developmental goals. ${ }^{81}$ This shows that the existing guidelines on SWFs' conduct must be further developed, in particular, to make clear whether development constitutes a legitimate objective for SWFs and how to regulate and assess such goals.

Furthermore, when we consider the use of SWFs for development purposes, it is important to remember that these funds are usually not directed solely at investment abroad; they might also invest domestically and any regulatory policy should take that into account. One such example is the Mubadala Development Company, established by the Abu Dhabi government to 'generate sustainable profits over the long-term', while delivering 'strong social returns to Abu Dhabi and the United Arab Emirates. ${ }^{82}$

The Bernstein et al study mentioned above shows some interesting findings regarding domestic and foreign investment which indicate that 'SWFs where politicians are involved in governance have a much greater likelihood of investing at home, while those relying upon external managers display a lower likelihood. ${ }^{83}$ One possible explanation for investing more in the internal market is that politicians

Udaibir S Das, Yinqiu Lu, Christian Mulder and Amadou Sy, 'Setting Up a Sovereign Wealth Fund: Some Policy and Operational Considerations' (August 2009) $9<$ http://www.imf.org/ external/pubs/ft/wp/2009/wp09179.pdf > accessed 22 November 2016.

Colin Smith, 'The Influence of Direct Investors in Infrastructure Investing' (May 2015) 2 $<$ http://www.pwc.com/gx/en/sovereign-wealth-investment-funds/publications/assets/pwcthe-influence-of-direct-investors-in-infrastructure-investing.pdf> accessed 22 November 2016: 'The most obvious shift in recent years has been the appetite of Sovereign and Stateowned investors to invest in Western infrastructure assets'.

81 See, eg, Khalid A Alsweilem, Angela Cummine, Malan Rietveld and Katherine Tweedie, 'A Comparative Study of Sovereign Investor Models: Sovereign Fund Profiles' (2015) <http:// projects.iq.harvard.edu/files/sovereignwealth/files/fund_profiles_final.pdf $>$ accessed 22 November 2016.

82 Mubadala Development Company, 'Overview' <http://www.mubadala.com/en/who-we-are/ overview> accessed 22 November 2016. Bernstein, Lerner and Schoar, 'The Investment Strategies of Sovereign Wealth Funds' (n 65) 1. 
would be 'more sensitive to the social needs of the nation' and 'willing to accept investments which have high social returns but low private ones. ${ }^{84}$

Regardless of the influence of national politicians on funds investment decisions, there are multiple scenarios in which SWFs could perform in ways that deviate from the traditional goals of wealth-maximisation, stabilisation, savings and reserve investment. For example, (i) funds may invest in industries abroad that bring benefits to the home country that are different from what would be considered the financial return on the investment (from dividends and increase in share value); (ii) development banks that also invest simply for profit might decide to direct their capital to foreign companies; (iii) even the entities that are traditionally considered to be SWFs (and thus that should be following commercial objectives, according to the 'privatising' approach) invest both domestically and abroad, and their decision on where to invest may be motivated by what will foster economic growth at their home country; and (iv) SWFs might decide to invest in development in other countries out of humanitarian considerations, as promoted by the World Bank. ${ }^{85}$

The relevance of recognising this potential shift in the policy goals of SWFs is that it implies a potential tension with the prevailing regulatory framework:

The central insight that may be derived from a functional examination of SWFs in developing states (whether or not resource management related), is that the expansion of the use of SWFs may be creating a fundamental tension within the current formal analytic framework, as the consequences of the form and function of SWFs established as a governance device may begin to deviate in substantial respect from the more traditional SWFs established as an instrument of macroeconomic policy.

In addition to this 'fundamental tension' in the analytical framework of SWFs, resulting from the differences in policy purposes, some authors have pointed to potential negative impacts of SWFs' investments in development, such as 'destabiliz[ing] macroeconomic management', 'undermin[ing] both the quality of

84 ibid 4.

85 Amy Stilwell and Geetanjali S Chopra, 'Sovereign Wealth Funds Should Invest in Africa, Zoellick Says' (2 April 2008) <http://web.worldbank.org/archive/website01016/WEB/0_C-278.HTM> accessed 22 November 2016.

86 Larry Catá Backer, 'International Financial Institutions (IFIs) and Sovereign Wealth Funds (SWFs) as Instruments to Combat Corruption and Enhance Fiscal Discipline in Developing States' (June 2014) <http://papers.ssrn.com/sol3/papers.cfm?abstract_id=2444308> accessed 22 November 2016. 
public investments and the wealth objectives of the fund' and 'bypassing budgetary controls. $^{87}$ Among the proposed solutions to these risks is the strengthening of governance structures and maintaining wealth-maximisation as the primary (while not exclusive) guideline for investment strategies. In other words, economic or social 'externalities' could not be the primary justification for an investment at the risk of losing a primary measure of accountability for fund managers. ${ }^{88}$

\subsection{Challenges of internal governance}

Looking at SWFs through the logic of private law has important consequences for their accountability mechanisms. If a SWF is like a private agent, then its accountability mechanisms gravitate around the idea that its main purpose is to maximise wealth. The implications of this logic for the governance of SWFs can be seen from two perspectives: one is concerned with the relationship between the fund and the capital recipient company. Another perspective is that of the relationship between the fund and its own constituents, which we refer to as 'internal' governance.

A private investor would be subject to the accountability mechanisms of its own shareholders, who might also be corporations owned by another set of shareholders, and so on and so forth until the ultimate shareholders are natural persons. The common trait in this logic is that the measure of accountability in all of the steps of the chain is maximisation of wealth: this is the base for the agency relationship established between the investor and the ones in charge of managing the investment. Thus, the Santiago Principles have been criticised for focusing on 'financial accountability' rather than 'public accountability.

In the case of SWFs, however, the chain of reasoning does not necessarily flow through all steps. First of all, because SWFs could be established for noncommercial purposes, as explained above, the criteria for verifying whether the fund is acting within the mandate given by its principal is different. Secondly,

Alan Gelb and others, 'Sovereign Wealth Funds and Long-term Development Finance: Risks and Opportunities' (2014) 2-3 <http://documents.worldbank.org/curated/ en/788391468155724377/Sovereign-wealth-funds-and-long-term-development-financerisks-and-opportunities> accessed 22 November 2016. ibid 11.

89 Afshin Mehrpouya, 'Instituting a Transnational Accountability Regime: The Case of Sovereign Wealth Funds and "GAPP”' (2015) 44 Accounting, Organizations \& Society 15. 
because the further we move up the chain of agency in the case of SWFs, the closest we get to the logic of public law and public interest. SWFs are ultimately figures of government, and their formation 'represents inevitably, a political moment in the life of a nation state. ${ }^{, 90}$ Moreover, they are often figures of specific governments that do not follow the same neoliberal approach to the economy as the countries in which they are investing: ' $[\mathrm{M}]$ ost SWFs are state-owned actors in state-dominated economies; yet when they go abroad, they claim forcefully to act as if they were private firms. ${ }^{, 1}$

As much as the literature on SWFs has increased dramatically over the past few years, it has not sufficiently dealt with this problem. Some of the initiatives that focused on the internal accountability of SWFs, such as the Santiago Principles, end up creating positive effects for matters of external governance, since they advocate for more transparency in respect of the fund's activities. However, those initiatives are not sufficient measures to deal with such a complex matter.

Thus, regulation of SWFs should seek to harmonise the different stakeholders that might be affected by their activities. Looking at their investment only through the lens of private law and private investment will not provide an adequate regulatory framework to deal with the many difficulties that arise. It is true that firms are often faced with similar issues, in the sense that they deal with a variety of stakeholders affected by their activities. However, what is unique about SWFs is precisely the relationship between the fund and its constituents at the home country. This is a challenge that private firms do not face (as their constituents will follow the logic of private law) and thus more attention needs to be focused on developing best practices for the internal governance of SWFs.

\section{Conclusion}

Since the recent growth in size and number of SWFs, a lot of attention has been focused on how these funds should be regulated. In particular, the potential use of these funds by their owners to advance political objectives has raised a lot of concern. Moreover, many scholars have argued that SWFs challenge the traditional

90 Gordon Clark and Asby Monk, 'Sovereign Wealth Funds: Form and Function in the 21st Century' (n 73) 3.

91 Gelpern (n 9) 3. 
concepts about the role of the state, as well as the division between public and private law.

These concerns have given rise to regulation that operates under the basic assumption that SWFs should behave as if they were private investors. Thus, until very recently, the vast majority of the regulation initiatives and proposals for SWFs looked at their activities only through the lens of private law and private investment. The main argument made in this paper is that there are specific circumstances where looking at SWFs solely through the lens of private law and private interest has proven to be disadvantageous.

First, even if SWFs were strictly wealth-maximising entities, a presumption against SWFs seems to exist, as if they were meant to advance the home country's geopolitical agenda (despite there being no strong evidence of SWF misbehaviour). This, in turn, leads to their activities being monitored under much stricter scrutiny than those of private investors. In a sense, the excessive fear of SWFs may lead to certain market inefficiencies, which is contrary to the very idea that SWFs should behave like private investors. SWFs are not only subject to transparency requirements that private investors are not, but they are also subject to strong political scrutiny at the recipient country that goes beyond the legal regulatory framework for foreign investment. Furthermore, either by political pressure or by specific regulation that seeks to protect the company from the fund's influence, ie, by preventing the fund from exercising voting rights, the presumption against SWFs might lead them to be a more passive investor, failing to fulfil its fiduciary duties towards the invested company. This would give even more power to the company's management and could allow it to take courses of action that do not maximise the value of the company.

While the concerns with SWFs' behaviour might have initially led to a binary approach to their motivations, as if they could only be either motivated (i) solely by the financial return on their investment (by dividends or increase in share value); or (ii) by geopolitical interests, of exercising influence over a certain region, country or sector, practice has proven this taxonomy wrong. Especially from 2010 onwards, many SWFs have started to make investment decisions that are expressly based, not only on financial return, but sustainability and development. Thus, a SWF's return on its investment can be beyond the mere financial benefit that it receives in the form of dividends or increase in share value.

In this sense, because of these non-commercial considerations and because of their particular ability to sustain long-term investment strategies, SWFs have proven to be important players in the financial market, precisely for the possibility 
of acting in spaces and opportunities that would not attract private investors. Furthermore, these types of investment, even though not based strictly on wealthmaximising considerations, have been performed without threatening the integrity of financial markets. Thus, 'privatising' SWFs and analysing their behaviour only through the lens of private law and private interest does not seem to be a comprehensive approach to their regulatory framework.

This article also seeks to highlight that the governance of SWFs is a complex matrix that involves several stakeholders. Most of the current proposals and discussions on regulating sovereign wealth funds are focused on the governance between the fund and the company in which it invests. There are, however, complex issues to be addressed in the governance relationship between the fund and its constituents in the home country where public law is of critical importance. Thus, the private law and private interest lens are not sufficient to deal with the internal governance of the fund. 'Privatisation' might provide good answers to deal with external governance, but it is unclear how much it contributes to internal governance. In part, this seems to be due to the fact that the majority of proposals for regulation of SWFs has been created and discussed in 'host' countries, and is thus based on the perspective and concerns of countries receiving capital.

While in practice SWFs have, over the past few years and especially with the increase of infrastructure and development-focused investments, blurred the lines between private and public power, solutions to increase internal accountability and to address the regulation of such non-commercial goals will probably not succeed if focused only on the 'public' feature of these funds, which are uniquely placed at the intersection of the public/private and national/international distinctions. 